\title{
Maritus/marita: Notes on the Dialectal Variation in Relation to Lexical Choices
}

\author{
Catarina Gaspar
}

(University of Lisbon)

\begin{abstract}
An analysis of the lexical choices between words with close or similar meanings in Latin epigraphy is one way to understand lexical variation in the language. This study focuses on formal, semantic and other reasons for the use of the words maritus, mariti (m.) and marita, maritae (f.) and their distribution in time and space in Latin epigraphy. This will allow us to better understand the relation between the juridical sense of these words and their usage in other contexts, such as poetry. This analysis of the use of maritus/marita can help us to understand semantic changes in Latin and the lexical change of the words, for instance their change into onomastic elements such as the name Marita. Also of interest is how the distribution of these words in epigraphic texts relates to the Romance languages, such as Portuguese, in which the masculine form maritus has been preserved but the feminine marita has been left behind. In this paper I approach variation in Latin through the analysis of lexical variation. I focus on epigraphic texts and assess the relevance of the data with respect to lexical choices among words that have the same or close meanings. Furthermore, I examine whether there is any connection between literary lexical choices and the other linguistic/grammatical traits of the texts.
\end{abstract}

\section{Keywords}

epigraphy; lexical variation; marital status; Latin; Romance languages 
Marita refers to a family relationship, namely marriage, and is related to coniux and uxor (applied to a legally married woman); and contubernalis, concubina and amica (all related to marital union de facto). We can translate marita as 'wife', similar to the masculine form maritus 'husband'; but in Latin, it had a more specific meaning related to the noua nupta, designating also a bride or a woman who has just married. ${ }^{1}$ Many dictionaries and lexica note its poetic usage and its chronology as 'postclassical', quoting examples from the poets and from epigraphy.

Benveniste (1969: p. 246) ${ }^{2}$ pointed out that the word maritus is specific to Latin and is linked to the juridical condition of the man as 'husband', legally married. He also noted that even though it is specific to Latin, the word was kept in later Romance languages. Benveniste also related the masculine and the feminine (maritus/marita) with the verb maritare in the intransitive sense ('to wed, to marry'), which is more common in the PostAugustan period but still quite rare; ${ }^{3}$ it is mainly used for the masculine, whereas women were given to be married, as the verb nupta dare suggests (Benveniste 1969: p. 241). ${ }^{4}$

Epigraphic testimonies give evidence of the future development of these words in Late Latin and in Romance languages. Maritare was kept in some languages, for instance Fr. marier and It. maritare; Pt., Prov., Cat. and Sp. maridar. The masculine maritus was much more common than the feminine form and was kept in Pt. marido and Sp. marido; Cat. marit; It. marito; Fr. mari. However, the feminine form, marita, had a different trajectory and was not kept in the Romance languages. Like uxor and coniux, it was sometimes replaced by mulier, as Adams (1972: p. 249) stated in his study of the Latin words for 'woman' and 'wife'. The same author stressed that mulier acquired its second sense, 'wife', in colloquial or nonformal speech, namely in possessive expressions such as 'my wife' (Adams 1972: p. 249). It could also be related to the use of the word in juridical texts. Either sphere could explain the success it had in Romance languages, as in the case of Portuguese.

In epigraphy as in literature, marita was always less common than uxor or coniux. Both uxor and coniunx referred to a woman legally married under the Roman law; $;^{5}$ as said above, marita mentioned also a legally married woman, but the one who had just married. However, these words don't have the equal occurrence in Roman law texts; for in-

1 See Thesaurus Linguae Latinae, VIII, 403, 1.48; see also Oxford Latin Dictionary, 1079-1089.

2 'Maritus est propre au latin. D'ailleurs il n'y a pas de mot indo-européen signifiant le «mari». Tantôt on dit "maître", skr. pati, gr. pósis ( l' «homme», lat. uir, gr. anér (ḋvท́@), alors que maritus qualifie le mari dans sa condition juridique.'

3 See Lewis \& Short (1879): 'mărīto, āvi, ātum, 1, v. a. 1. maritus, I. to give a husband to one; hence to wed, marry, give in marriage to a man. I. Lit. (post-Aug. and rare): "Vitellii filiam," Suet. Vesp. 14: "lex (Augusti) de maritandis ordinibus," i.e. imposing fines for celibacy in all classes, id. Aug. 34: "lex Julia de maritandis ordinibus," Gai. Inst. 1, 178; Ulp. Fragm. 11, 20; "pleonastically: matrimonia," i.e. to conclude, make, App. Dogm. Plat. p. 26. Hence, absol., to marry, take a wife: “maritandum principem suaderent," Tac. A. 12, 6.' (retrieved 02.06.2017 from http://www.perseus.tufts.edu/hopper/morph?l=marito\&la=la\#lexicon).

4 'On ne peut pas non plus attacher au rôle de la femme le verbe lat. Maritare, même à la date tardive où il apparaît: maritare comme verbe actif signifie "apparier, conjoindre", et comme verbe intransitif il se dit plutôt de l'homme que de la femme. Cette situation lexicale negative, l'absense d'um verbe propre, indique que la femme n'épouse pas, elle est épousée.'

$5 \quad$ See Treggiari (1991: pp. 6-7). 
stance, in the Digesta, according to R. Černoch, ${ }^{6}$ the occurrences of uxor (981) and mulier (1134) are close (although mulier does not always means 'wife'); coniunx is only attested as part of verbs; and marita is not attested at all, just the masculine forma maritus is found 818 times. R. Černoch concludes that the combination 'husband' and 'wife' in the Digesta is designated by maritus/vir and uxor/mulier.

In terms of the evolution of uxor and coniunx in Romance languages, the trajectory of these words was like that of marita, they also disappear even though they were so common in epigraphic and literary texts. The progressive disappearance of these three words can be a consequence of the progressive reduction of their use and of their replacement by mulier.

Among previous studies related to marital relationships and their lexical expression, I would like to highlight Jeppesen-Wigelsworth (2010). This study expanded on previous research based on the epigraphic corpora, such as volume VI of CIL. ${ }^{7}$

According to Jeppesen-Wigelsworth (2010), marita had epigraphic success mainly between the first and third centuries A.D. However, there is an irregular geographic distribution of the word in epigraphy, with most of the known examples found in Rome and some regions in Italy. It has also been found in inscriptions from Moesia Inferior/Dacia (modern Romania), North Africa and the Iberian Peninsula. ${ }^{8}$

In Hispania, the use of marita can be assigned to specific regions: the southern part of Lusitania, Baetica and to specific cities in Hispania Citerior, such as Tarraco. We might say that this is clearly a Mediterranean distribution.

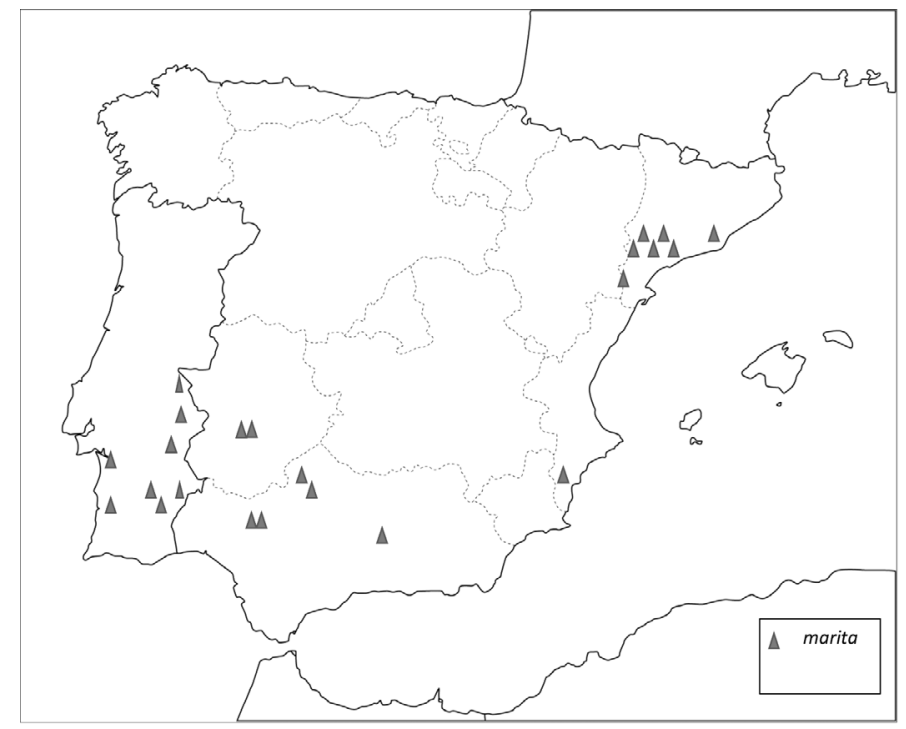

[Figure 1 - Distribution in Iberian Peninsula]

6 A very special thanks to Radek Černoch for this information about the Digesta.

7 See Harrod (1909) and Treggiari (1991).

8 See data available in epigraphic databases: Epigraphik-Datenbank Clauss / Slaby (EDCS) and Epigraphic Database Heidelberg (EDH). 
Geographic and chronological data can be useful in understanding how the lexical evolution of these words resulted in the success of the masculine form and the near disappearance of the feminine form in Late Latin in Early Christian epigraphy. For instance, even in regions where it was quite common, such as North Africa, we find only a few examples among early Christian Latin epigraphy. ${ }^{9}$ Moreover, within the 23 texts from Hispania, only one (n. 12) from Peñaflor (Seville) is early Christian, from the end of fourth century to the beginning of the fifth century A.D. ${ }^{10}$

The lexical choices between words with close or similar meanings in Latin epigraphy can be due to formal, semantic or other reasons. It is, however, difficult to evaluate the epigraphic texts in terms of lexical choices and substitutions because of their formulaic nature. The lexical variation we find in epigraphy is less evident than what we find in literary or other non-literary texts. For instance, in Lex Romana Wisigothorum (also known as Breviarium Alarici) we find the masculine forma maritus, but married women are designated as uxor, mulier and femina. ${ }^{11}$ Nevertheless, we can say that the lexical choices in epigraphic texts are in line with the other types of texts and in line with the dynamic changes in the language.

Herman (2000) considered several reasons to explain a lexical substitution and/or lexical choice, including:

- regularization of inflection patterns: '[words] belonging to special inflectional paradigms or having complicated irregularities in their forms give way to simpler alternatives with commoner and more regular inflectional patterns' (Herman 2000: p. 98);

- substitution by communicative needs: 'replace some short words with longer ones of greater phonetic substance' (Herman 2000: p. 99);

- semantic reasons: 'A word can have some nuance of meaning that makes it more suited to the lives and attitudes of the people of the time, and thus comes to be used in preference to a more semantically neutral ancient word, even though they both have more or less the same meaning' (Herman 2000: p. 101).

In the case of the feminine word marita, the regularization of inflectional patterns nor the semantic reasons explain its progressive disappearance in epigraphy. We must therefore consider other forces, such as sociohistorical changes that might explain the lexical selection and variation: mainly, social reasons and aesthetic-formal reasons.

Jeppesen-Wigelsworth (2010) analysed the various uses of the Latin words for wife - uxor, coniux, marita, contubernalis and amica - in epigraphic texts, according to the following criteria: ${ }^{12}$

- physical location (household tomb or columbaria);

- status of partners;

- epithets, age and length of marriage;

9 For more information about the marriage in Late Antiquity see Grubbs (2000: pp. 563-565).

10 See Carbonell Manils, Carranza Cruz, Gimeno Pascual \& González Germain (2009: p. 488).

11 See Domínguez Agudo (2003: pp. 94-96).

12 See Jeppesen-Wigelsworth (2010: p. 34). 
- date of inscription;

- occupation of spouses; and

- the military status of male partners.

Jeppesen-Wigelsworth concluded that 'status appeared as a key factor'; marita was a poetic and quite rare term for wife, that 'show[s] a slight upward trend in usage' (Jeppesen-Wigelsworth 2010: p. 232) during the Aurelian period. She also concluded that marita was used for the freeborn women who could afford larger tombs. ${ }^{13}$ This economic and social profile suggests upper classes with greater literacy who were more likely to have literary $^{14}$ influences in their epitaphs and in their lexical choices. Furthermore, these choices and epigraphic texts could have been the model followed by those who were from lower classes in Rome and other regions of the empire.

One may ask, does the use of marita in Hispania lead us to similar conclusions? Is it related to the freeborn upper classes and to some specific types of monuments? Could it give us evidence of literacy? If we conduct a linguistic analysis of the inscriptions in which marita occurs, do we find relevant features of vulgar Latin?

To answer these questions, I analyse the epigraphic evidence of marita from the Iberian Peninsula.

Regarding the types of monuments, we find common types among the local communities, though we cannot relate all of them with a high social range. In Lusitania arae, tabulae, similar to those found in Baetica and Hispania Citerior; although, it is only in Lusitania that can be found examples of cupae (n. 4, 7 and 8). In Baetica, the major part of examples known today are from arae and tabulae. The same can be seen in Hispania Citerior; in this area, we must highlight one tabula ansata (n. 16) and one pedestal of a statue (n. 23) found in Barcino. The pedestal was no doubt related with the social elites of the city.

\section{Lusitania}

(1) D(is) M(anibus) s(acrum) / M(umia) L(uci) filia Cu/pita ann(orum) XXXXIIII / Q(uintus) L[-] N[-] marite et / Antonia Fundana / et Mumia Rufina / filias(!) matri pi/issime posue/

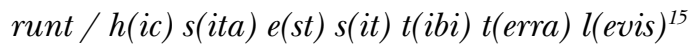

(2) — / an(nos?) L Claud(ius) / Thalassinus / marite me/rentissime / h(ic) s(itus) e(st) s(it) t(ibi) $t$ (erra) $l(\text { evis })^{16}$

(3) D(is) M(anibus) s(acrum) / Minatia Faus/tina an(norum) XXXX / h(ic) s(ita) e(st) s(it) t(ibi) t(erra) l(evis) / Antonius Ro/mulus mari/tae pientissi/mae f(aciendum) $c$ (uravit $)^{17}$

(4) $D($ is $) \cdot M($ anibus $) \cdot s($ acrum $) / C($ aiae $) \cdot V a l e r i a e / C(a i) \cdot \boldsymbol{m}($ aritae $) \cdot A m m(a) e / a n-$ $n o r(u m) \cdot L \cdot I \cdot / h(i c) \cdot s($ ita $) \bullet e(s t) \bullet s(i t) \cdot t($ ibi $) \cdot t($ erra $) \cdot l($ evis $) \cdot 18$

13 'It is possible that marita was replacing uxor as the popular upper-class term for wife' (Jeppesen-Wigelsworth 2010: p. 232). 'Thus, an uxor or a marita tended to be a freeborn woman who came from a financially well-off household, which could afford a larger tomb' (idem: p. 233).

14 See the testimonies of the word marita in literature - Jeppesen-Wigelsworth (2010, chapter 2).

15 Alcácer do Sal, Portugal. See CIL 02, 00038 (p. 802) = IRCPacen. n. 331; LLDB n. 16387.

16 Santiago do Cacém, Portugal (ancient Mirobriga). See CIL 02, 00031 = IRCPacen n. 181; LLDB n. 16380.

17 S. Salvador de Aramenha, Marvão, Portugal (ancient Ammaia). See CIL 02, 00166 = IRCPacen n. 464.

18 Monte da Salsa, Brinches, Serpa, Portugal. See HEp 4, 1994, 1000; ACS (1997: p. 107, n. 4). 
(5) $D($ is) M(anibus) s(acrum) / C(aius) Marcius Tus/culanus / an(norum) L $h$ (ic) s(itus) e(st) $s$ (it) $t$ (ibi) t(erra) l(evis) Ap/ronia Maxima / marita pientis/sima d(e) s(uo)f(aciendum) c(uravit) ${ }^{19}$ (6) FALIIIA(?) Avita an(norum) / XXXh(ic) s(ita) e(st) s(it) t(ibi) t(erra) l(evis) / L(ucius) T[-] Rufinus / marite sue / fecit cura/vit $\{t\}^{20}$

(7) D(is) M(anibus) s(acrum) / [m(onumentum)] p(osuit) Oricllo(?) / [Fl]orice Agate / marite pient/issime cum / quam vixit / communes / annos XXXX/II mense $(m) I^{21}$

(8) D(is) M(anibus) s(acrum) / Iul(ia) Cleopatr(a) / ann(orum) XXXIII / Heren(nius) Priscus / marit(e) piissime / h(ic) s(ita) e(st) s(it) t(ibi) t(erra) l(evis) ${ }^{22}$

(9) Amphoninae Iul(iae) Nymp(h)e / h(ic) s(ita) e(st) s(it) t(ibi) t(erra) l(evis) / ann(orum) LV h(ic) s(ita) e(st) s(it) t(ibi) t(erra) l(evis) / marit(ae) optimae Hedyphnus / socrae optimae matri pi/issimae / f(ecit $)^{23}$

(10) D(is) $\cdot M($ anibus $) \cdot s($ acrum $) /$ Flaviae / Elpidu / benemerenti / mar(itae $) \cdot C($ ornelius $)$ Vrbicus $^{24}$

\section{Baetica}

(11) D(is) M(anibus) s(acrum) / Aelius Pot[iti]/anus vixit [ann(os)] / XXXXI pius in [suis] / marita e[t fili(i?)] / bene me[renti] / fece[runt] / h(ic) s(itus) e(st) [s(it) t(ibi) t(erra) l(evis?) $]^{25}$ (12) [-- ob]sequens mari[-tae, -tus / - - ex?]cedens filio [-- / - - ] - servus Dei b[i/xit - - ] ann(is) - XX · Ru[- - - - - - ]s Dei et +[- - / - - ] +E[- - ] / - - - - ?26

(13) Memor(iae) aetern(ae) / Clod(iae) Euporiae ann(orum) / XXXX dies(!) XXVIII / castae et abstinentis bonae / indolis matronae nec alie/ni cupida par opinionis suae / sancta in coniuge(!) pia quoq(ue) / natae famulisq(ue) benigna / obsequentissima dignis hanc / omnis aetas amavit quae mu/tata patria casu rapta mane[t] / relictaq(ue) nata reddidit in pe/regre plura meruisti mari/to digna testimonio eius ut / [-]CV[-] in saeculo mater / Cast[-] maritae incompara/bili [mat]r(i?) castissimae fecit ${ }^{27}$

(14) D(is) M(anibus) s(acrum) / Fab(ia) Mirine / vix(it) ann(os) XXV/ marite sanc/tissimae Ge/minus memori/[am p(osuit)] h(ic) s(ita) e(st) s(it) t(ibi) t(erra) l(evis) $)^{28}$

19 São Pedro, Campo Maior, Elvas, Portugal. See IRCPacen, n. $593=$ AE 1990, 00485.

20 Herdade da Camugem, Vila Boim, Elvas, Portugal. See IRCPacen n. 585 = Tantimonaco (2016: p. 254); LLDB n. 17569.

21 Beja, Portugal (ancient Pax Iulia). See IRCPacen n. 259; LLDB n. 17396.

22 Beja, Portugal (ancient Pax Iulia). See IRCPacen n. 261; LLDB n. 17401 (note that the mention in the LLDB refers to piissime).

23 Mérida, Spain (ancient Emerita Augusta). See CIL 02, 00530 = ERAEmerita, n. 15.

24 Mérida, Spain (ancient Emerita Augusta). See Del Hoyo (1989: pp. 91-93, n. III).

25 Sevilha, Spain (ancient Italica). See CIL 02, 01139 (pp. 698, 1037) = CILA-02-02, $00417=$ ERIt $00082=$ HEp-04, 00731.

26 Peñaflor, Sevilha, Spain (ancient Celti). See HEp 18, 2009, 315 = AE 2009, 566 = Carbonell Manils, Carranza Cruz, Gimeno Pascual, \& González Germain (2009: p. 487).

27 Córdoba, Spain (ancient Corduba). See CIL 02-07, 00439 (retrieved 02.06.2017 from http://edh-www. adw.uni-heidelberg.de/inschrift/suche?hd_nr=\&land=\&fo_antik=\&fo_modern_fundstelle=Córdoba\&lit

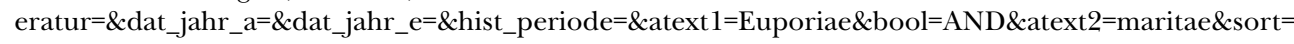
hd_nr\&anzahl=20).

28 Posadas, Córdoba, Spain (ancient Detumo). See HEp. 1, 00284 = CIL 02-07, 00738 (retrieved 02.06.2017 from http://eda-bea.es/pub/list.php?refpage=\%2Fpub\%2Fsearch_select.php\&quicksearch=Mirine); LLDB n. 26227. 
The first inscription (n. 1) was carved in a funerary ara, with ornaments, that could be considered a rather expensive monument. The deceased spouses were freeborn, probably with some local social significance. Among its linguistic traits is the graphic variation $E$ in place of $A E$ (in marite, piissime); we also find inflectional problems and confusion of the morphological form of the casus in the inscription's use of filias for the nominative filiae (Herman 2000: pp. 54-55).

The same orthographic oscillation between $E$ and $A E$ can be seen in other inscriptions: $E$ is used in texts n. 2, 6, 7, 8, and 14, all from Lusitania and Baetica. However, the $A E$ is retained in twelve inscriptions from Lusitania and Baetica (n. 3, 4, 9, 13) and from Hispania Citerior (n. 15, 16, 17, 18, 19, 21, 22 and 23).

\section{Hispania Citerior}

(15) D(is) M(anibus) s(acrum) / Secunda[e] / annor(um) XXXV / Flavianus ma[r]/itae merenti s(it) $t$ (ibi) $t$ (erra) $l(\text { evis })^{29}$

(16) D(is) M(anibus) / Ulp(iae) Marcianae / vixit an(nos) XXX / L(ucius) Cassius Iunia/nus maritae / karissimae ${ }^{30}$

(17) D(is) M(anibus) / [3]EVSILICOLLIANAE / [3] Sulpicius Ursinus / maritae incompar/ abili vixit an $(n)$ is / $X X X V^{31}$

(18) D(is) M(anibus) / \{h\}ave Caecilia Dori[s] / L(ucius) Lucretius Martinu[s] / VIvir Aug(ustalis) et ma[g(ister) Lar(um?)] / maritae incomp[arabili] / cum qua sine [querella vixi] / ann(os) XXVIII hic [nemini] / fuit inimicu[s] / Caecilia mihi kariss[ima] ${ }^{32}$

(19) $[D($ is $)] M$ (anibus) / [-]viae Sigeri/[na]e(?) M(arcus) Fabius / Censo[r] mari/tae karissim[ae] / fecit ${ }^{33}$

(20) Numitorius L[-] / marita et Munnian[-] / Expeditiensi deae Com[-] / bene qui ob [-] $]^{34}$ (21) D(is) M(anibus) s(acrum) / Baebiae Ursi/nae maritae / dulcissimae / et merentis/simae $\{H\} I /$ lerdensi / Sul(picius) Primiti/v(u)s VI(vir) Tarra(conensis) / fec(it) ${ }^{35}$

(22) [A]chaidi / [a]nn(orum) XXX / [I]ul(ius) Primus maritae / [op]timae l(ocum) «s(epulturae)» C(ai) Satt(i) Mercat(oris) $)^{36}$

29 Peal de Becerro, Jaén, Spain (ancient Tugia). See CILA III, $550=$ HEp 5, 1995, 522.

30 Alcudia de Elche, Elx (Elche), Spain (ancient Ilici). See CIL 02, 05953 = CIL 08, 10012 (p. 2080) = IRPAlicante $00073=$ IRIlici-02, 00049a.

31 Tortosa, Spain (ancient Dertosa). See AE 2013, 00928.

32 Tarragona, Spain (ancient Tarraco). See CIL 02, 04290 (p 973) = RIT 00408 = CIL 02-14-03, 01242 = EDCS05503320 (retrieved 02.06.2017).

33 Tarragona, Spain (ancient Tarraco). See CIL 02, 06122 = RIT $00563=$ CIL 02-14-03, 01676 = EDCS05601189 (retrieved 02.06.2017).

34 Tarragona, Spain (ancient Tarraco). See RIT 00021 = CIL 02-14-02, 00818 = EDCS-03400009 (retrieved 02.06.2017); photo available in http://db.edcs.eu/epigr/bilder.php?bild=PH0009972. G. Alföldy (RIT 21) accepted that Marita here is an onomastic element. Although, we can also admit other interpretations to 1. 1-2: Numitorius L(ucii) / marita or Numitorius L(ucii) [f(ilius) - ] / marita. The position of the text in the last line, in the middle of the stone, suggests that the text we can see is just half of the total text. So, the lines above could have more words, at least one or two, namely the name of the wife or of her husband in 1.1 .

35 Tarragona, Spain (ancient Tarraco). See RIT 00373 = CIL 02-14-03, 01241 = EDCS-03400130.

36 Tarragona, Spain (ancient Tarraco). See RIT 00488 = CIL 02-14-03, 01434 = EDCS-03400173. 
(23) Corneliae / L(uci) filiae Secun/dinae L(ucius) Valer(ius) / Rufus maritae / optimae et bene / de se meritae et / Cornelia Secunda / mater fil(iae) pientiss(imae) / l(ocus) d(atus) d(ecreto) $d(\text { ecurionum })^{37}$

As for the Vulgar Latin traits we see in these inscriptions phonological and orthographic traits, as well as some syntactic features. There is evidence that the oscillation between $E$ and $A E$ was more common in Lusitania and Baetica than in regions in the eastern part of Iberian Peninsula. We may say that inscriptions from these other areas have less vulgar or Late Latin traits.

Indeed, among inscriptions from Lusitania we find other relevant features:

- accusative form standing for the nominative (n. 1) - filias;

- $\quad$ errors due to the difficulties in reading the minuta by the stonecutters, as noted by Tantimonaco (2016: p. 254), suggesting that the FALIIIA stands for VALERIA (n. 6);

- a littera superflua in the last line of n. 6, in curavitt;

- $\quad$ in n. 7, the personal name Oricclo is used instead of Oriculo - with the double $C C$ and syncope of the vowel ${ }^{38}$ (Tantimonaco 2016: p. 252). In the same text, we find cum quam instead of cum qua; the ablative singular form is replaced by the accusative singular, which is also very common in Late Latin morpho-syntax ${ }^{39}$ (Tantimonaco 2016: p. 252).

In the corpus of inscriptions we are dealing with, the epigraphic texts using marita in Hispania Citerior have no significant linguistic features. Therefore, if we propose that the use of correct forms of marita is related to the economic and social profile of upper classes with greater literacy, and therefore more likely to have literary influences in their epitaphs and lexical choices, this fits perfectly with what we know about the communities of Tarraco. It also fits perfectly with the example known in Barcino (n. 23), which is the only honorific inscription in our corpus and clearly correlated with social and economic elites.

With regard to Lusitania and Baetica, the epigraphic texts could have referred to the local elites in cities such as Mirobriga and Ammaia, but there is also evidence that those who were from lower classes followed the elite models in the use of the word marita, as well as in the use of the uxor and coniunx. ${ }^{40}$

As said above, the monuments' typology cannot help us, since there are multiple typologies related to individuals of all social groups. With regard to the other criteria used by Jeppesen-Wigelsworth (2010), even onomastics cannot give us entirely reliable information about the social profile of the deceased and the economic status they held

37 Barcelona, Spain (ancient Barcino). See CIL 02, 04554 (p. 982) = IRC-04, 00126.

38 See Herman (2000: pp. 34-35). The cognomen Oriculus/- $a$ is also known in North Africa: CIL VIII, 7450 and CIL VIII, 19561; however, it is not a very common cognomen.

39 Cf. Herman (2000: pp. 53-54).

40 We find the same trend in inscriptions with uxor and conjunx, denoting difference between the Western provinces, Lusitania and Baetica, and the Hispania Citerior, more specifically, the eastern part of Tarraconensis. 
in their communities. Nevertheless, linguistic traits can give us some information; we can surmise that the 23 texts from the Iberian Peninsula pertain to freeborn upper classes, although not to specific types of monuments. Linguistic analysis of the inscriptions where marita occurs shows that relevant features of vulgar Latin appear only in the western regions (Lusitania and Baetica). This can be due to the wide range of social groups involved, the date of the inscriptions and the low literacy level of those engaged in producing the text and carving it into the monument ${ }^{41}$ (see inscription n. 6).

In terms of the lexical evolution, I wish to highlight the single example from the Iberian Peninsula in which Marita appears as a personal name (n. 20). This is relevant because we find examples of this name in other regions (see n. 24, 25, 26, 27), but mainly in places where the noun marita is not so well known.

(24) D(is) [M(anibus)] / Carosso [-] / et Maritae ux(ori) vi(vi) p(osuerunt $)^{42}$

(25) Socrates viv $\langle u>$ s sibi et Aeliae Mar/itae monumentum fecit // $\Sigma \omega \kappa \rho \alpha ́ \tau\rceil \eta \varsigma \zeta \tilde{\omega} v \dot{\varepsilon} \alpha v \tau \tilde{\omega} \kappa \alpha i$

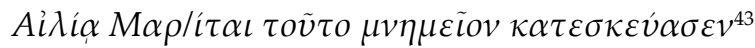

(26) M(arcus) Varinius / M(arci) l(ibertus) Celer sibi / et Variniae Ma/ritae uxori et Pri/migeniae et Pyral/idi fliti)s et genero / [C]urio Alcimo vivos(!) $f(\text { aciendum) } c \text { (uravit })^{44}$

(27) Quinctia / P(ubli) l(iberta) marita / ann(orum) LXX h(ic) s(ita) e(st) / t(estamento) f(ieri) i(ussit) / Adauctus l(ibertus) / fecit ${ }^{45}$

All of these seem to appear in the same chronological strand. However, it is interesting that the personal name has a geographical distribution different from the noun marita. It is very difficult to set a precise chronology for the words in language, but we may surmise that the personal name had a different and possibly later dissemination in the empire, mainly into the eastern part and to north. This may be why there is only one example of the personal name in Iberian Peninsula.

\section{Conclusion}

Analysis of the use of marita in epigraphic texts from the Iberian Peninsula allows us to see the geographic distribution from the eastern Mediterranean area into the southern part of Lusitania. The social, economic and cultural profile of those who are represented in the epigraphic texts corresponds to those in freeborn upper classes. Linguistic analysis shows that relevant features of vulgar Latin related to diastratic variation occurred

41 See Tantimonaco (2016) regarding the problems in reading and understanding the minuta by the stonecutters.

42 Cf. Metz, Belgium; CAG-57-02, p. 195 = EDCS-47600584.

43 Izmit, Turkey (ancient Nicomedia, Pontus et Bithynia); CIL 03, $00330=$ CIL 03, 13649 = EDCS-26600102 = HD037450.

44 Philipi, Macedonia; CIL 03, 00682 (p 989) = CIL 03, $07338=$ HD050095.

45 Carnutum, Petronell, in Pannonia Superior; CIL 03, 04520 (p. 1770) $=$ H073504. We may also admit that marita in 1.2 is a personal name: Quinctia / P(ubli) l(iberta) marita. 
mostly in the western part (Lusitania and Baetica) of the Iberian Peninsula, which may be due to the wide range of social groups involved and the age of the inscriptions.

The progressive disappearance of the word marita in early Christian epigraphy can be explained by the lexical substitution process. The other words, uxor and coniunx suffered a similar progressive replacement by mulier, although this cannot be explained just because of juridical and cultural, mostly religious, changes with respect to marriage, because in Romance languages such as Portuguese the masculine form of maritus has been preserved, but the feminine marita, uxor and coniunx were left behind. As Herman (2000: p. 101) wrote about the reasons for lexical choices: "Sometimes the semantic reasons are less straightforward, and the change could be better described as stylistic. The exact nature of such development is not always easy for us to reconstruct." We may say that the fate of marita can be due to stylistic reasons combined with the frequency of use.

Lexical choices and dialectal variation remain a challenge for us. However, if we try to combine different points of view on language and on words, perhaps we will advance our knowledge of ancient languages.

\section{Abbreviations}

ACS 1997 Lopes, M. C., Carvalho, P. C., \& Gomes, S. M. (1997). Arqueologia do Concelho de Serpa. Serpa: Câmara Municipal de Serpa.

AE L'Année Épigraphique, Paris, 1888-.

CAG Flotté, P. (2005). Carte Archéologique de la Gaule. Metz 57-2. Paris: Académie des Inscriptions et Belles-Lettres.

CIL Corpus Inscriptionum Latinarum.

CILA González Fernández, J. (1991). Corpus de Inscripciones Latinas de Andalucía, 02-02. La Vega (Italica), Sevilla. Sevilha: Junta de Andalucía, Dirección General de Bienes Culturales.

EDCS M. Clauss, A. Kolb, \& W. A. Slaby, Epigraphik-Datenbank Clauss / Slaby (retrieved 02.06.2017 from http://db.edcs.eu/epigr/).

EDH Epigraphic Database Heidelberg (retrieved 02.06.2017 from http://edh-www.adw.uniheidelberg.de/home).

ERAEmerita García Iglesias, L. (1973). Epigrafía Romana de Augusta Emerita. Madrid: Facultad de Filosofía y Letras Universidad Complutense.

ERIt Canto, A. (1983). La epigrafía romana de Itálica. Madrid: Universidad Complutense de Madrid.

HEp Hispania Epigraphica. Madrid, 1989-.

IRBarc Mariner Bigorra, S. (1973). Inscripciones romanas de Barcelona. Barcelona: CSIC.

IRC Fabre, G., Mayer, M., \& Rodá, I. (1997). Inscriptions romaines de Catalogne. IV Barcino. Paris: Diffusion de Boccard.

IRCPacen Encarnação, J. (1984). Inscrições Romanas do Conventus Pacensis. Subsídios para o estudo da romanização. Coimbra: Universidade de Coimbra. 
IRIlici Corell, J. (2012). Inscripcions romanes del País Valenciŕ VI: Ilici, Lucentum, Allon, Dianium $i$ els seus territoris. Valčncia: Universitat de Valčncia.

IRPAlicante Rabanal, M. A., \& Abascal, J. M. (1985). Inscripciones Romanas de la Provincia de Alicante. Lucentum, 4, 191-244.

LLDB Adamik et al., Computerized Historical Linguistic Database of Latin Inscriptions of the Imperial Age (retrieved 02.06.2017 from http://lldb.elte.hu/admin/index.php).

RIT Alföldy, G. (1975). Die römischen Inschriften von Tarraco. Berlin: Walter de Gruyter.

\section{Bibliography}

Adams, J. N. (1972). Latin words for 'woman' and 'wife'. Glotta, 50(3/4), 234-255.

Benveniste, E. (1969). Le vocabulaire des institutions indo-européennes. 1. Économie, parenté, société. Paris: Les Éditions du Minuit.

Carbonell Manils, J., Carranza Cruz, J., Gimeno Pascual, H., \& González Germain, G. (2009). Una inscripción cristiana de Peńaflor (Sevilla). Anales de Arqueología Cordobesa, 20, 483-490.

Clackson, J., \& Horrocks, G. (2007). The Blackwell history of the Latin language. Oxford: Blackwell.

Del Hoyo, J. (1989). Nuevas lecturas de epigrafía hispana. Espacio Tiempo y Forma, s. II, História Antigua, t. II, 81-94.

Domínguez Agudo, M. I. (2003). Estudio léxico de 'Iura y Leges' en el drecho romano vulgar (Memória para optar al grado de Doctor). Madrid: Universidad Complutense de Madrid, Facultad de Filología.

Fruyt, M. (2000). La creation lexicale. Généralités appliquées au domaine latin. In C. Nicolás, \& M. Fruyt (Eds.), La création lexicale en Latin (pp. 11-48). Paris: Presses de l’Université Paris-Sorbonne.

Fruyt, M. (2011). Latin Vocabulary. In J. Clackson (Ed.), A Companion to the Latin Language (pp. 144-156). Oxford: Wiley-Blackwell.

Grubbs, J. E. (2000). Marriage. In G. W. Bowersock, P. Brown, O. Grabar (Eds.), Late Antiquity. A Guide to the Postclassical World (pp. 563-565). Cambridge: The Belknap Press of Harvard University Press.

Harrod, S. (1909). Latin terms of endearment and family relationships. Princeton, MA: Princeton University Press.

Herman, J. (2000). Vulgar Latin. University Park, PA: The Pennsylvania State University Press.

Jeppesen-Wigelsworth, A. D. (2010). The portrayal of roman wives in literature and inscriptions (unpublished doctoral dissertation). Calgary, Alberta: Department of Greek and Roman Studies, University of Calgary.

Lewis, Ch. T., \& Short, Ch. (1879). A Latin Dictionary. Oxford: Clarendon Press (retrieved 02.06.2017 from http://www.perseus.tufts.edu/hopper/text?doc=Perseus\%3atext\%3a1999.04.0059).

Meyer-Lübke, W. (1911). Romanisches etymologisches Wörterbuch. Heidelberg: Carl Winter.

Saller, R. P., \& Shaw, B. D. (1984). Tombstones and Roman family relations in the principate: civilians, soldiers and slaves. The Journal of Roman Studies, 74, 124-156.

Tantimonaco, S. (2016). Vltra Anam flumen. Apuntes sobre la alfabetización en la Lusitania Meridional. In J. Carbonell Manils, \& H. Gimeno Pascual (Eds.), A Baete ad fluvium Anam: Cultura 
epigráfica en la Bética Occidental y territorios fronterizos. Homenaje al profesor José Luis Moralejo Álvarez (pp. 243-264). Alcalá de Henares: Universidad de Alcalá.

Treggiari, S. (1991). Roman Marriage: Iusti Coniuges from the Time of Cicero to the Time of Ulpian. Oxford: Clarendon Press.

\section{Catarina Isabel Sousa Gaspar PhD / cgaspar@fl.ul.pt}

